\title{
Influence of Past on Present: A Naturalistic Study of Ghosts
}

\section{Arjun Dev Bhatta, $P h D$}

Lecturer, Tribhuvan University

Email: abhatta44@gmail.com

\begin{abstract}
This article analyzes and evaluates Henrik Ibsen's most controversial drama "Ghosts" from naturalistic point of view. Naturalism views human life in relation to internal and external environment. It insists on the effect of the past that shapes the present life of human beings. Based on this philosophy of life, this article examines how the life of the leading characters Mrs. Alving and her son Oswald has been influenced. Mrs. Alving's present values and views on life have a concern with conventional and religious past whereas Oswald's philosophy of life is guided and governed by his dead father. This article also shows heredity and genetic transformation are biological facts that affect human life. Thus, the object of this article is to explore how human beings are controlled by the inescapable past.
\end{abstract}

Keywords: fatal disease, inevitability, influence, naturalism, detachment

\section{Introduction and Objective}

The objective of this article is to investigate the notion of naturalism in Henrik Ibsen's Ghosts (1881) mainly through the analysis of some of the major characters. Ghosts is a typical naturalistic play that deals with the life of individuals in relation to their environment. The nineteenth century theorist Emile Zola first developed and applied the movement to his novel. His contemporary Henrik Ibsen gave currency to the movement in his social plays. Naturalism accentuates scientific objectivism, determinism, plausibility and detachment without any traces of mysticism, supernaturalism and exoticism. Inspired by scientific method of investigation and observation, the naturalistic writers, like scientist, observe life objectively to depict the real world. It assumes human beings are not free individuals; their behaviour, action, and thought are controlled and guided by instinct, emotion and socio-economic background. Their fate has essentially been determined by environmental forces to which they have no control. All their struggle for free will is futile. Murfin and Ray state: "Human beings are at the mercy of a variety of external and internal forces as if they are marionetters whose movements are entirely determined by forces beyond their control" (223). Naturalistic works tend to deal with either biological or socio-economic or psychological determinism. It takes man as a complex collection of atoms and the genetic function that affect a special trait and internal and external factors. M. H. Abraham and Geoffrey Galt Haltman observe: 
"Naturalism as thesis produced by post-Darwinian biology in the nineteenth century, held that a human being exists entirely in the order of nature and does not have a soul nor any mode of participating in religious or spiritual world beyond the natural world (270). It states human beings have no soul, no mind, no self and no choice; our impulse, action and language are determined by heredity, environment and uncontrolled past events. This article aims to analyze how these factors have affected the present life of Mrs. Alving and her son Oswald in Ibsen's play Ghosts.

\section{Methodology and Result}

This paper applies literary naturalism as theoretical approach to analyze Ibsen's Ghosts. In so doing, I have analyzed the major factors responsible for influencing the life and character of Mrs. Alving and Oswald on the conceptual framework developed by Emile Zola, Henrik Ibsen, Brian Johnston and Martin Esslin.

Zola stresses on truthfulness, accuracy and observation in his study of human beings. The concept of scientific method of observation and experiment Zola draws from Claude Bernard who stressed the scientific, experimental method that implied a deterministic view of nature. According to Esslin, this "experimentation discloses the chain of cause and effect behind seemingly arbitrary phenomena" (69). For Zola, the novelist, as a doctor, is an observer and experimentalist whose observation should be based on exact representation of nature, listen to nature and write under its direction. In 'The Experimental Novels' he writes:

In fact, the whole operation consists in taking facts in nature, then studying the mechanism of facts, acting upon them, by the modification of circumstances and surroundings, without deviating from the laws of nature. Finally, you possess knowledge of the man, scientific knowledge of him, in both his individual and social relations. (647)

The naturalistic literature experiments on man and detects the human machinery in their relation to internal and external environment. It sees each individual as entirely submissive to the laws of nature and compel to act accordingly. Zola says:

The true naturalistic novelists are analyzers of man, in his individual and social relations. They operate on the characters, the passions, on the human and social data, in the same way that the chemist and the physicist operate on inanimate things, as the physiologist operates on living beings. Determinism dominates everything.(648)

In his essay 'Naturalism on the Stage', he further defines novelists as: 
Naturalistic novelist no longer looks on man as an intellectual abstraction; he is a thinking animal, who forms part of nature, and who is subject to the multiple influences of the soil in which he grows and where he lives. The novelist no longer separates his character from the air he breathes; he does not describe him because of any rhetorical need, as the didactic poets did. (10-11)

The naturalistic school of philosophy is an aftermath of Charles Darwin's theory of evolution and its corollary "survival for the fittest". His monumental work 'Origin of the Species' and its theory that the various forms of human life evolved from one another by some process of transformation, the struggle for the existence, the expulsion of the unfit can be considered a milestone in the development of naturalism. Thus, the naturalists claim that heredity is one of the underlying factors that determines human actions, behaviour, belief and life. They are much motivated by strong instinctual drives and always in tension caused by the factors beyond their control. In Emile Zola's phrase they are nothing more than 'human beast', who cannot escape compulsive instincts like hunger, greed and sexuality. In this sense, naturalism exposes bestiality of men, not the rational and idealistic behaviour. Moreover, naturalistic works encompass uncouth or sordid subject matter such as sexuality, prostitution, filth, poverty, greed, hunger and incurable disease.

Like novel, theatre should be exact representation of this sort of human life, Zola believes. He writes in 'Naturalism on the Stage' the drama that does not "focus a strictness of form based on scientific nature will become blunted and more and more inferior" (5).He anticipates a naturalistic playwright would put his characters in his proper surroundings, and analyze all the physical and social causes in a scientific manner as does Chemistry in the study of compounds and their properties. For Zola, the theatre was a stage of observation, a study and picture of real life, not a stage of "amusement for the mind and intellectual guessing game" (13). The role of dramatist according to him is to:

.... put a man of flesh and bones on the stage, taken from reality, scientifically analyzed, and described without one lie. . rid us of fictious characters, of these symbols of virtue and vice which have no worth as human data. . environment to determine the characters and the characters to act according to the logic of facts combined with logic of their own disposition. . . no one will tell us anymore unbelieving stories, when no one will any longer spoil the effects of true observation by imposing romantic incidents, the result of which destroys even the good parts of a play. . the playwright returns to the source of science and modern arts, the study of nature, to the anatomy of man, to the painting of 
life in an exact reproduction more original and powerful than anyone has so far dared to risk on the bards. (6)

Zola insists on perfect exactness on stage to produce inevitability. It creates an illusion of reality through a range of dramatic and theatrical strategies. The language they speak on the stage is more natural, flexible and more sonorous.

Ibsen was highly impressed by the naturalism developed in novel by Emile Zola and French painters of the day. It was right time for him to bring complete changes in conventionality in writing and performing dramas. He initiated revolutionary departure not only in style but also in thematic innovation. His basic method in his prose plays is to present his central characters, male or female, in a situation where their expectations are seriously disappointed, and their imagined world is destroyed, or shown to be beyond their reach. In the realistic manner, he portrays middle-class people whose life is affected by internal and external environment. Ghosts is a play that deals with the theme of the effect of past on present, heredity problem and sexuality. Yves Chevrel states:

Ibsen's dramas are tragedies adopted to modern conditions, although mythic ideas of tragic fatality and God's will have been replaced by new myths of the scientific world view. The sense of tragic fatality and God's will is fueled by the inevitable determination of milieu and heredity (qtd. in Rossi).

Ibsen abandoned verse for prose to expose human reality in scientific manner. Issues like heredity, alcoholism, incest, venereal disease, frustration, unhappy social relationship, and marital problems are his exclusive subjects to be presented on the theatre. Thus, his characters represent the real situation people face in the society as its real members. He writes:

The illusion I wished to produce was that of reality. I wished to leave of the reader's mind the impression that what he had read had actually happened . . . The many everyday insignificant characters, whom I have intentionally introduced, would have become indistinct and mixed up with each other had I made them all speak in rhythmic measure. We do no longer live in the days of Shakespeare. . My play is no tragedy in the ancient acceptation. My desire was to depict human beings and therefore I would not make themselves speak the language of the gods. (qtd. in Raymond 40)

Ghosts is a drama that brought the biggest stir in Europe. The play attacked the values of the middle-class particularly the institution of marriage, law and order and both filial and societal duty. Society for Ibsen has hypocrisies and obscure diseases. He claims communities, church, and even family are the enemies of human freedom. This 
philosophy of life postulated by Ibsen through his realistic plays that shocked the respectable middle-class audiences everywhere. This is the reason the play become so insipid to the general public. The voice of the critics against the play in Norway was so great that people afraid to buy the play. It was condemned and banned. Ludwig Joseph says, "The play is one of the filthiest things ever written in Scandinavia" (qtd. in Mayer 12). The play exposed ugly truth and taboo subjects such as sex, incest and venereal disease. It also sets a large question mark against morality based on duty, against marriage and Christianity, and the whole of existing society. The king Oscar II at a dinner organized in Ibsen's honour at the Royal palace expressed that Ghosts was not a good play and that Ibsen shouldn't have written it. After a moment's silence the playwright replied, "Your majesty I had to write Ghost" (qtd. in McFarlane 52). He wrote Ghosts as a response to the objections raised by Nora's flight from her husband and children in A Doll's House. He said, "I had to write Ghosts; I could not stop at $A$ Doll's House; after Nora I had to create Mrs. Alving (qtd. in May 60).

Ibsen's Ghosts as a purely naturalistic play exposes human beings as product of spiritual and biological past. "Ghosts sets out an exploration of unresolved past conflicts which gives rise to a new crisis in the present" (Rossi). The role Mrs. Alving performs throughout the play is governed by spiritual and social forces whereas her son, Oswald's life is dominated by biological determinism. The power of past in the play is so dominant that it has altered entire life of both mother and son.

Mrs. Alving has inherited much of the characteristics of her parents. They were religious and conventionally minded people who raised her in accordance with their social norms and values. Although she was emotionally attached to Pastor Manders, her parents prompted her in a respectable marriage with Captain Alving. She performed wifely duty to her husband as society expects from a woman. But, within the first years of marriage, she felt herself miserable because her husband turned debauchery. He loved hedonistic life and found much pleasure in drinking, smoking and whoring. She felt hard to spend life with her debauched husband so she sought Pastor Manders' refuse. But Pastor Manders was himself much more conventional than Mrs. Alving that is whyhe promptly sent her to the path of duty and obedience. In the years that follow she begins to understand that it is the wrong of church and society that compel a woman to live with a man whose life is morally dead, and also destroying the life of her child. With this question, she begins to abandon the prejudiced old ideas and takes firm action.

Mrs. Alving initiates to improve the worse situation of Alving family and preserve the reputation with intelligence. She takes control over her husband clinging with him, listening to his ribald talks and even drinking with him. Mrs. Alving has decided to stay 
with her husband and "to cover up the "corpse" of her married life with respectable trappings" (Lavrin 81). She manages her housemaid, Johnna with whom Captain Alving had an affair, and takes complete responsibility of Regina, Captain Alving's illegitimate daughter. Similarly, she sends Oswald to Paris to save him from his father's contaminated and immoral life. Depriving herself of her son's presence is her great sacrifice because Oswald is only one who can give life meaning to her. Now Mrs. Alving is not giving much importance to her religious feelings. She tries to rid social conventions, beliefs and traditions that hindered the free development of her individual life.

Mrs. Alving decides to build Captain Alving's Memorials to preserve his social respectability and honor and "to refute all the rumours and dispel any doubt" (1. 52). She investigates all the money into that Memorial so that Oswald will not inherit anything from his father. She says, "That was my purchase price. I don't want that money to go to Oswald. Whatever my son inherits shall come from me and no one else" (1.53). She feels relieved because the burden and fear of her husband is no more there. The son has returned home after many years. She assumes Oswald will be the free soul, uncontaminated by the past, unhaunted by the ghosts. Her years' sacrifice has been compensated by her son's presence in the house, and her lonely years are to be redeemed by the presence of her son. She rejects the past, and through her son she will initiate her new life. She says to Pastor Mander, “... this long hideous farce will be over. From tomorrow onwards, I shall feel as if my late husband had never lived in this house; there will be no one here but my son and his mother" (1.54). She realizes in order to live a happy life one has to release the past.

In the first act of the play, we see Oswald's interest in sex and liquor. In the kitchen he flirts with his house-maid, Regina. She screams: "Stop it, Oswald! Don't be silly! Let me go! (1.54). The sounds of furtive sex-play from the kitchen make Mrs. Alving recall of her past maid when Captain Alving flirted with her. Mrs. Alving's aspiration for a new life with her son is shattered forthwith. She is badly shocked not because Regina is Oswald's half-sister but because the ghost of the past revisited the house which she had already removed from her mind. Now she realizes it is quite hard for her to release the past. She further notices some of the characteristics of his father gliding on him. Like his father, Oswald feels boredom, he is only lying on the bed, smoking, drinking and flirting. She realizes Oswald is product of biological past of his father. And the ghost of her husband has still strong grip in the house. Even Pastor Manders sees the appearance of ghost in Oswald, for Oswald is smoking his father's pipe, and for a moment, the Pastor sees the father returned. Oswald's philosophy of life is also similar to his father, not of her own. Oswald does not see the life the way Mrs. Alving observes. Mrs. Alving sees 
life with a spiritual view point. For her, spiritual happiness comes from devoting oneself to sacrifice and calling. But Oswald's philosophy of life is based on physical ones. He believes in the pleasure of the day, and insists on sensual pleasure that comes from joyful work. This is the reason he finds no happiness in his house and detests the life in Norway. For him the Norwegian life is vale of tears in which duty, not happiness is the first consideration. The life is meaningful only if there is joy, complete physical joy. Mrs. Alving is startled and says, "The joy of living. . .? Can there be any salvation in that? (2.80). She observes Oswald's hedonism is the product of his father, not hers.

For Ibsen, heredity disease is the symbol of deterministic force that destroy humanity. The present life of an individual concerns with his/her parents and the place he/she was born into. What happened to the individual in life was to a large extent determined by what happened to him/her in the early years. Ibsen applies this deterministic view of life in this play. Like conventional influences, ancestral influences play dominant role in shaping the present life of human beings. Johannsen says, "The ancestral influences are the "ghosts" in genetics, but generally the belief in ghosts is still powerful" (138). He takes an ancestor influence in heredity the "transmission conception'. In this sense, conventional disease transmitted to Mrs. Alving and biological disease transmitted to Oswald can be seen as ghosts. Sprinchorn observes: "To represent the ineluctable forces of the past, to give them a specificity, Ibsen chose a disease - syphilis - that, like old ideas that had wormed their way into the souls of the living, could be transmitted from parent to child" (114). The fetal disease syphilis as a metaphor is central in Ghosts.

The disease remains dormant in Oswald's body for many years. He first experienced its struck in Paris. He consulted a specialist who told him that it was inherited. He supposed the doctor was wrong because at that moment he had not been told the truth about his father. Oswald says to his mother, "If it had been something I'd inherited - something I wasn't to blame for" (2.75). This remark of Oswald would deny the deterministic philosophy of the play. He believes it is the result of his free choice in abroad, a choice to lead a bohemian life. His happy existence in Paris is the source of his illness. He tells his mother that he did not lead a dissolute life there in Paris. Now, the unidentified bacteria 'spirochetes' has gradually been working in his body. He is feeling physical and mental debility. He has lost his talent in artistic creation, and realizes his health, happiness and future irreparably ruined. Oswald does not feel 'joy of living' in the house; everything has turned into something ugly in that house. In this condition, he cannot bear the torture of remorse, great deadly fear. He says he does not know anything about his father, but only one thing that he knows is the pursuit of joy, of sensual pleasure of his father destroyed his whole life.Reinert observes: "Oswald's paying for his 
father's sexual promiscuity with paralysis and dementia had power to shake complacency into pained - and therefore angry - awareness (216). His free will is crippled by the ghost of his father. He does not find light and sunshine in the house that is why he is going to leave the house. In his desperate condition his only hope is Regina, his salvation and 'joy of life'. He cannot go on enduring the agony of mind alone. The microscopic organisms transmitted from his father have destroyed Oswald completely.

At the climactic moment of the play, a fire breaks out in the orphanage. The orphanage she had built was not her love and reverence to her husband. It was to hide her husband's ugly secret and generate in public the feeling that they were model spouses. Now, she believes one part of past is complete. But within the moment of satisfaction, she falls in great anxiety learning that Oswald is also burning. The juxtaposition of the fire in the orphanage and the fire in Oswald's body caused by disease is explicit. There is also direct association of fire with the disease in the first act of the play. When Oswald first appears, we see him smoking his father's pipe. He reveals a humorous event that one evening, in his good mood, his father kept him in his knee and let him smoke his pipe. He smoked as hard as he could, which made him sick. In the third act, Oswald reveals that his brain is on fire. He says, "Everything'll burn, till there is nothing left to remind people of my father. Here am I burning up, too" (3.90). The pursuit of joy, of sensual pleasure which destroyed Captain Alving is the principal cause of Oswald's mental collapse.

Oswald's inheritance of syphilis from his father is open to Mrs. Alving. Her awareness of Oswald's disease signals the beginning of her education. When she discovers the inevitability of the past, she begins to calculate great errors she made in the past. Her heroism, freedom and enthusiasms turn into pessimism. At the turning point of the play, she suddenly realizes her efforts to preserve her husband's social reputation, the concealment of Captain Alving's debauchery, her inability to tell Regina the straight truth about her birth, the illusive letters to Oswald are great error of her life. In this regard Corrigan says, "Every significant choice that Mrs. Alving has ever made and the resultant action of such a decision is determined by these ghosts of the past rather than by intellectual deliberation" (175). She alwayslooked on Oswald as an extension of herself, but now learns that Oswald is himself a ghost, an extension of his dead father carrying his father's traits in his diseased vein. When she knows Oswald's importance to physical pleasure 'the joy of life', she realizes it as powerful truth. She atones for the errors she committed in the past. She realizes that she saw her husband not a human being but only a disgusting animal. She admits that she was herself responsible for not giving her husband sexual pleasure that forced him turn to taverns and brothels. At this critical juncture, she is obliged to reveal the truth she had concealed for twenty-eight 
years. In fairness to him, she openly reveals the fact that Oswald's syphilis was not a result of his carefree life in abroad, but a fatal disease transmitted from one generation to another. All she had written to him was merely a tale of illusion. She also discloses that Regina is Captain Alving's illegitimate daughter and Oswald is her kin brother. His infatuation and demand to marry her is antisocial norms. Regina decides to abandon Mrs. Alving's long parentage and follows Engstrand, her supposed father. She believes she has no right to help the 'invalid'. Oswald merely gazes her; he cannot do anything. Now, at the very end of the play, Mrs. Alving is committed to be Oswald's helping hand. She will administer him morphine when he gets attack. She still seems entirely faithful to her old ideas of sacrifice and duty; she will devote herself to caring for Oswald even though he is nothing but a living corpse. In the last terrible moment of the drama, Oswald demands the pills in his sudden attack. But in his deranged mental state, he only mutters "The sun. . . the sun". Mrs. Alving is staring him in speechless horror.

Ibsen's Ghosts as a naturalistic play tells us that individuals are not free to live according to their own choices. Their life, characters and behaviour are governed and determined by overarching pressure of heredity and environment. The modern men are compelled to face all these obstacles. Within this naturalistic purview Ibsen exposes modern life which has become victim of past. Brian Johnston writes:

Ibsen declared that modern man was sailing with a corpse in the cargo, he was distinguishing between the past as ghosts that refuse to be exorcised from the world of living, and that past which is a vital and indispensable part of man's present. . Human life is continuation of the past in the present; but the task of finding a place for man's most vital past in the present is serious, for if man is to transcend in his past he must show himself the equal of it - must, in Hegelian terms, "sublate" it, not evade it. (52-53)

In this play, both mother and son have become the victim of these diseases over which they have no control. Oswald's famous speech proves this:

My whole life ruined - irreparably ruined - and all through my own thoughtlessness. All the things I meant to do in the world. . . I can't think about them. Oh, if only I could start afresh and have my life over again. . . . If only it had been something I'd inherited - something I wasn't blame for. . . But this! It's so shameful to have thrown away my health and happiness everything in the world - so thoughtlessly, so recklessly. . My future - my life itself. (3.75) 
The old ideas and prejudices instilled on Mrs. Alving during a conventional upbringing have ruined her life whereas the infected blood transmitted from his father has destroyed Oswald. According to Corrigan Mrs. Alving and Oswald are "the victim of a two-fisted fate which takes the form of the laws of heredity in a mechanistic world and the stultifying and debilitating conventions of respectability (171). The ghost of the past is still lurking in both son and mother. Mrs. Alving makes it clear in one of the key speeches of the play:

I'm haunted by ghosts. . . But I'm inclined to think that we're all ghosts. It is not only the things that we've inherited from our fathers and mothers that live on in us, but all sorts of old dead ideas and old dead beliefs, and things of that sort. They're not actually alive in us, but they're rooted there all the same, and we can't rid ourselves of them. I've only to pick up a newspaper, and when I read it I seem to see ghosts gliding between the lines. I should think there must be ghosts all over the country - as countless as grains of sand. (2.61)

For Mrs. Alving all these conventions, traditions, and received ideas that hinder the human spirit are ghosts. The defunct ideas and beliefs have determined and governed our way of life and thinking. Marx wrote, "The traditions of all the dead generation weigh like a nightmare on the brains of the living" (qtd. in Sprinchorn113). Not only the dead hands of the past, but also the contemporary ways and conventions of society affect the life of individuals. Thus, all kinds of defunct theories, all sorts of defunct beliefs, all sort of defunct social norms and values are prime cause that infect the lives of the people. Mrs. Alving calls them "the cause of all the trouble in the world" (2.58). The law and order have forced Mrs. Alving to remain faithful to her dissolute husband, and sacrifice her entire life for the preservation of his reputation. She feels coward so she could not bring her husband's filthy life to open, nor could she reveal to Oswald Captain Alving's profligacy, nor could she tell Regina the truth behind her birth. The truth behind this long concealment is her fear of society. Mrs. Alving calculates her effort to seal off the past have made the present more dangerous and complected. She is sad because she has kept the family scandal secret to preserve the ideal society demands. Mrs. Alving expresses her remorse to Pastor Manders: "I should never have hushed up the truth about my husband's life. But in those days, I dared not to do anything else - I was too much of a coward. ... If I were the woman I ought to be, I should take Oswald on the one side and say: 'listen, my boy, your father was a dissolute man" (2.58-59). We can say that Mrs. Alving's life's sacrifice for her husband and son, the mission to improve the world and Oswald's dream to create beauty in life are simultaneously annihilated by the ghosts of past. In this situation, they are compelled to face the power of the past as mere helpless creatures. 


\section{Conclusion}

The play Ghosts is a purely a naturalistic play. It affirms that nature is the whole of reality which no human beings can escape. The play also tells that the power of contaminated heredity destroys the determined ideal life of successive generation. Captain Alving's debauchery destroys familial happiness and ruins the life of both mother and son. It designates that Oswald's behaviour is entirely determined by heredity and environment. He is bound to live under multiple compulsive instincts imposed by nature. The focus of the play goes on to psychological and bestial aspects of human beings. Mrs. Alving's strategies to ignore the influence of profligate Captain Alving have ruined her family. Oswald's syphilis transmitted from his father designates how powerful, determinant and inevitable the contaminated heredity is. Above all, the play exposes the fact that our choices and actions are the result of preexisting conditions. We do not have free will or capacity to choose between alternatives. We cannot change our life but the natural forces like heredity and environment play vital role in determining our life and fate.

\section{Works Cited}

Abrams, M. H. and Geoffrey Galt Harpman. A Glossary of Literary Terms. Thomas Wadsworth, 2005.

Corrigan, Robert W. “The Sun Always Rises: Ibsen's “Ghosts” as Tragedy?” Education Theatre Journal, vol. 11, no. 3, Oct. 1959, pp. 171-80. JSTOR, www.jstor.org/stable 3204799.

Esslin, Martin. "Naturalism in Context." The Drama Review: TDR, vol. 13, no. 2, Winter 1968, pp. 67-76. JSTOR, www.jstor.org/stable/1144411.

Ibsen, Henrik. Translated by Peter Watts. Ghosts and Other Plays. Penguin Books, 1964. 19-102.

Johannsen, W. "The Genotype Conception of Heredity.” The American Naturalist, vol. 45, no. 531, Mar. 1911, pp. 129-159. JSTOR, www.jstor.org/stable/2455747.

Johnston, Brian. "The Corpse and the Cargo: The Hegelian Past in Ibsen's Naturalistic Cycle." The Drama Review: TDR, vol.13, no. 2, Winter 1968, pp. 47-66. JSTOR, www.jstor.org/stable1144410.

Lavrin, Janko. Ibsen. London UP, 1950.

May, Keith M. Ibsen and Shaw. Macmillan, 1985.

McFarlane, James, ed. "Henrik Ibsen: Preliminary Notes for Ghosts." Henrik Ibsen. Hazell Watson and Viney, 1970.

Meyer, Michael. "Introduction.” Henrik Ibsen: Plays: Three. Eyre Methuen, 1980. 1129. 
Murfin, Ross and Supryia M. Ray. The Bedford Glossary of Critical and Literary Terms. Bedford Books. 1997.

Raymond, William. Drama from Ibsen to Brecht. Chatto \& Windus, 1968.

Reinert, Otto. "Ibsen and Mimesis." Scandinavian Studies, vol. 80, no. 2, Summer 2010, pp. 213-30. JSTOR, www.jstor.org/stable/40908164.

Rossi, Riikka Johanna. "Disgust-Melancholia as a Mood of Modernity: Naturalistic Constellations of Melancholia" in J. K. Huysmans' A Vau-l'eau, Emile Zola's Nana and Henrik Ibsen's Ghosts. Excavatio, 2019. 31.

Sprinchorn, Evert. "The Transition from Naturalism to Symbolism in the Theatre from 1880-1900.” Art Journal, vol. 45, no. 2, Summer 1985, pp. 113-119. JSTOR, www.jstor.org/stable 776788.

Zola, Emile. "The Experimental Novels." Critical Theory since Plato, edited by Hazard Adams. Harcourt. 1992. 645-55.

---. "Naturalism on the Stage." Playwrights on Playwriting: from Ibsen to Ionesco, edited by Toby Cole. Cooper Square P. 2001. 5-14. 